\title{
Bacteria in Himalayan glacial ice and its relationship to dust
}

\author{
S. Zhang ${ }^{1,2}$, S. Hou ${ }^{1}$, Y. Wu ${ }^{3}$, and D. Qin ${ }^{1}$ \\ ${ }^{1}$ State Key Laboratory of Cryospheric Sciences, Cold and Arid Regions Environmental and Engineering Research Institute, \\ Chinese Academy of Sciences, Lanzhou 730000, China \\ ${ }^{2}$ Department of life science, Shangqiu Normal University, Shangqiu 476000, China \\ ${ }^{3}$ School of Life Science, Lanzhou University, Lanzhou 730000, China
}

Received: 3 July 2008 - Published in Biogeosciences Discuss.: 29 August 2008

Revised: 20 November 2008 - Accepted: 20 November 2008 - Published: 15 December 2008

\begin{abstract}
Concentrations and community diversity of bacteria from 50 segments of a $108.83 \mathrm{~m}$ ice core drilled from the East Rongbuk (ER) Glacier $\left(28.03^{\circ} \mathrm{N}, 86.96^{\circ} \mathrm{E}, 6518 \mathrm{~m}\right.$ above sea level) on the northeast slope of Mt. Qomolangma (Everest), covering the period 950-1963 AD, were investigated by epifluorescence microscope, DGGE and ShannonWeaver index analysis. Bacteria in the ER core were identified as $\beta, \gamma$-proteobacteria and Firmicutes group, with $\gamma$ proteobacteria being the dominance. Different bacterial population was identified along the core, reflecting the effects of climatic and environmental changes on the bacterial distribution in the glacial ice. There are four general periods of bacterial diversity, corresponding to four phases of dust abundance revealed by $\mathrm{Ca}^{2+}$ concentrations. However, a previously suggested positive correlation between bacterial and $\mathrm{Ca}^{2+}$ concentrations was not indicated by our observations. Instead, a weak negative correlation was found between these two parameters. Our results suggest that bacterial community diversity, rather than concentrations, might be a suitable biological proxy for the reconstruction of past climatic and environmental changes preserved in glacial ice.
\end{abstract}

\section{Introduction}

The relationship between concentrations of microorganisms and dust in glacial ice has been studied for polar regions and the Tibetan Plateau (TP). For instance, Mitskevich et al. (2001) analyzed 10 samples from the Antarctic glacial ice over Vostok. They observed that the maximum diversity of bacterial cells was correlated with organic detritus, and was present in samples with maximum density of microorganisms. By using confocal microscopy, Priscu et al. (1998)

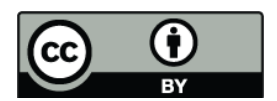

Correspondence to: S. Hou (shugui@lzb.ac.cn) identified cyanobacterial cells in the sediment of the ice cover of Lake Bonney, Antarctica. Zhang et al. (2003) suggested that the concentrations of total and culturable microorganisms from 23 samples of the Tibetan Malan ice core were correlated with dust content. By using these samples and $\delta^{18} \mathrm{O}$ as a proxy for temperature, Yao et al. (2006) further suggested that more microorganisms were associated with cold periods, and fewer with warm periods. It is suggested that microorganisms in glacial ice depend on the transportation of micro-particles during glacier growth (Zhang et al., 2003). Sediment particles can serve as nutrient-enriched (inorganic and organic) micro-zones for the establishment of a physiologically and ecologically complex microbial consortium that is capable of contemporaneous photosynthesis, $\mathrm{N}_{2}$ fixation, and decomposition (Priscu et al., 1998). However, in a shallow ice core from the Himalayan Yala Glacier in the Langtang region of Nepal (Yoshimura et al., 2006), algal biomass in each annual layer from 1984 to 1994 AD was negatively, but insignificantly correlated with micro-particle concentrations. Results of samples from the upper $12.5 \mathrm{~m}$ of a $22.4 \mathrm{~m}$ long ice core drilled from Muztagh Ata in the northwestern TP also showed an insignificant correlation between concentrations of micro-particle (1-30 $\mu \mathrm{m}$ in diameter) and bacteria (Xiang et al., 2006). These imply that, although micro-particles may serve as the source and nutrition for bacteria, it is only one of the factors that determine bacterial concentrations in glacial ice. Therefore more efforts are necessary to verify the feasibility of reconstructing past climatic and environmental changes by means of glacial microorganism. In addition, most of the above work suffered from limited samples, and some of the Tibetan ice cores are not well dated. Here we investigate the bacterial concentrations of 50 samples collected along a $108.83 \mathrm{~m}$ ice core recovered from the ER Glacier. Among them, 13 samples were analyzed for bacterial community diversity. We wish to extend (with more reliable statistics) the current understanding of bacterial concentrations and community diversity and

Published by Copernicus Publications on behalf of the European Geosciences Union. 


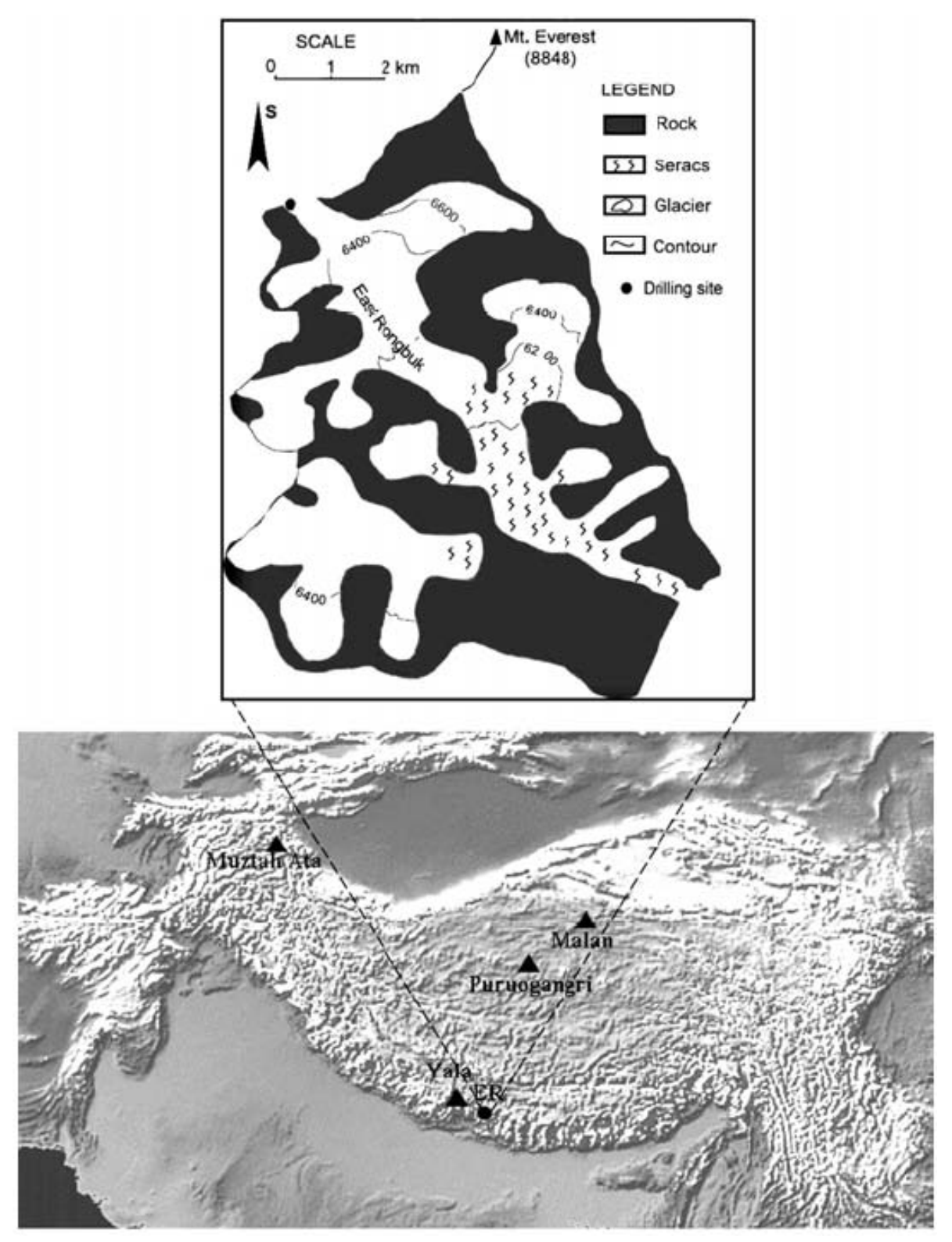

Fig. 1. Location map of ice core drilling sites.

to study their relationship with dust content in the Himalayan glacial ice. This work extends our previous results of the seasonal variations of abundance and species diversity of culturable bacteria recovered from Himalayan glacial ice (Zhang et al., 2007).

\section{Materials and methods}

\subsection{The ice core}

A $108.83 \mathrm{~m}$ ice core, diameter $9.4 \mathrm{~cm}$, was drilled to the bedrock on the col of the ER Glacier (Fig. 1) by using an electromechanical drill in a dry hole in September-October
2002. The ER Glacier covers an area of $48.45 \mathrm{~km}^{2}$ with a length of $14 \mathrm{~km}$. Its equilibrium line of $6250 \mathrm{~m}$ above sea level is believed to be the highest among all glaciers on Earth. Repeat surveys with a Sokkia GSS1, a Global Positioning System (GPS), in 1998 and 2002 did not identify horizontal movement at the drilling site. Visible stratigraphy shows no hiatus features, and the ice layers are horizontal. The average annual net accumulation is about $400 \mathrm{~mm}$ water equivalent as determined by snow pit and an $80.36 \mathrm{~m}$ ice core study (Hou et al., 2002). Bore-hole temperature ranged from a minimum of $-9.6^{\circ} \mathrm{C}$ at $20 \mathrm{~m}$ depth to $-8.9^{\circ} \mathrm{C}$ at the bedrock. The relatively high annual accumulation and low temperature throughout the glacial ice ensure the preservation of 
high resolution environmental and biological record. After drilling, the ice core was transported in a frozen state to a cold room at about $-20^{\circ} \mathrm{C}$ and was stored there until analysis.

\subsection{Ice core measurements and dating}

At first, this core was split axially into two equivalent portions for different measurements. One portion was melted continuously into 3123 samples and analyzed for major soluble ions, hydrogen isotopes $(\delta \mathrm{D})$, and Bismuth at the Climate Change Institute, University of Maine, USA, and oxygen isotopes $\left(\delta^{18} \mathrm{O}\right)$ at the State Key Laboratory of Cryospheric Sciences, Chinese Academy of Sciences, China. $\mathrm{Ca}^{2+}$ analysis was performed via suppressed ion chromatography (Dionex 4000 series instruments) with a CS12 column, $125 \mathrm{ml}$ loop, which was described in detail by Ivask et al. (2001). The other half core was sampled discontinuously for measurement of gases at Laboratoire de Glaciologie et Géophysique de l'Environnement, France, gas stable isotopes at Laboratoire des Sciences du Climat et de l'Environnement, France (Hou et al., 2004), trace metals at Korea Polar Research Institute, lead isotopes at Department of Applied Physics, Curtin University of Technology, Australia, and bacteria (present in this paper) at the State Key Laboratory of Cryospheric Sciences, Chinese Academy of Sciences, China. A total of 50 samples were collected for bacterial cell concentrations, roughly proportionally but discontinuously along this core. The vertical length of these samples was in the range $0.25-0.48 \mathrm{~m}$, with detailed depth intervals as follows: $29.15-29.47 \mathrm{~m}$, $30.34-30.79 \mathrm{~m}, \quad 32.11-32.47 \mathrm{~m}, 32.47-32.72 \mathrm{~m}, 33.89-$ $34.34 \mathrm{~m}, 36.09-36.42 \mathrm{~m}, 37.89-38.24 \mathrm{~m}, 40.05-40.38 \mathrm{~m}$, $41.10-41.55 \mathrm{~m}, \quad 43.15-43.45 \mathrm{~m}, \quad 45.35-45.75 \mathrm{~m}, \quad 48.56-$ $48.86 \mathrm{~m}, 49.58-50.03 \mathrm{~m}, 52.95-53.25 \mathrm{~m}, 54.80-55.20 \mathrm{~m}$, $55.64-55.94 \mathrm{~m}, \quad 57.25-57.65 \mathrm{~m}, \quad 58.41-58.86 \mathrm{~m}, \quad 59.46-$ $59.76 \mathrm{~m}, 62.00-62.38 \mathrm{~m}, 62.70-63.15 \mathrm{~m}, 63.69-63.99 \mathrm{~m}$, $64.64-64.99 \mathrm{~m}, \quad 65.33-65.71 \mathrm{~m}, \quad 67.22-67.47 \mathrm{~m}, \quad 68.21-$ $68.66 \mathrm{~m}, \quad 69.56-69.88 \mathrm{~m}, 71.25-71.55 \mathrm{~m}, 72.85-73.20 \mathrm{~m}$, $74.54-74.89 \mathrm{~m}, \quad 75.22-75.62 \mathrm{~m}, \quad 76.34-76.64 \mathrm{~m}, \quad 78.96-$ $79.26 \mathrm{~m}, 79.59-79.94 \mathrm{~m}, 80.08-80.33 \mathrm{~m}, 83.88-84.36 \mathrm{~m}$, $85.05-85.35 \mathrm{~m}, \quad 87.02-87.27 \mathrm{~m}, \quad 89.74-90.09 \mathrm{~m}, \quad 92.05-$ $92.35 \mathrm{~m}, 93.15-93.45 \mathrm{~m}, 94.98-95.43 \mathrm{~m}, 97.03-97.31 \mathrm{~m}$, 97.51-97.84 m, 98.09-98.54 m, 100.06-100.51 m, 102.58$102.93 \mathrm{~m}, \quad 104.34-104.79 \mathrm{~m}, 105.69-105.99 \mathrm{~m}, 106.96-$ $107.31 \mathrm{~m}$. Among the above 50 samples, 13 (Fig. 2) were analyzed for bacterial community diversity.

The ice core was annually dated to $1534 \mathrm{AD}$ to a depth of $98.0 \mathrm{~m}$ using seasonal variations of $\delta \mathrm{D}$ and soluble ions, and the timescale was verified by identifying large volcanic horizons from the first high-resolution measurements of Bismuth on an Asian ice core (Kaspari et al., 2007). The bottom $2 \mathrm{~m}$ of the ice core was dated to 1498-2055 years BP using methane and isotopic composition of atmospheric $\mathrm{O}_{2}$ (Hou et al., 2004). Below $98.0 \mathrm{~m}$ annual layer counting is not possible due to layer thinning, thus prior to $1534 \mathrm{AD}$ the ice core was dated using a flow model. The details of dating were described by Kaspari et al. (2007; 2008).

\subsection{Ice core decontamination}

In order to obtain reliable microbiological data, it is essential to eliminate the potential contamination caused during drilling, transportation, storage and sampling. This procedure was established according to Willerslev et al. (1999) and Christner et al. (2005) with minor modification. The ice core was sampled in a class-100 unidirectional flow clean bench, which was located inside a $-20^{\circ} \mathrm{C}$ class- 1000 dedicated cold room. Personnel involved wore clean room garbs and polyethylene gloves. At first, the potentially contaminated surface layer was removed (about $2 \mathrm{~mm}$ thick) by shaving with a sterile stainless steel scalpel. Afterwards, the operator changed to a new pair of gloves and the second veneer layer was shaved off by using a new scalpel. This procedure was repeated three times and about $6 \mathrm{~mm}$ thick veneer layer was removed. Then still in the cold room (temperature was switched to $4^{\circ} \mathrm{C}$ ), the remaining inner core was rinsed with $300 \mathrm{ml}$ sterile high purity water of $>18 \mathrm{M} \Omega$ to melt away about $2 \mathrm{~mm}$ of the exterior surface. The remaining inner core was then placed into a sterile glass beaker for melting completely at $4^{\circ} \mathrm{C}$ in the dark. At the same time, the scraped surface ice was collected and used as controls. The same procedure was used to process an artificial ice core of ultrapure water as an analytical blank.

\subsection{Direct cell counts}

Treatment of samples by SYBR Green-II (Molecular Probes, Inc.) was modified from Yamagishi et al. (2003). Fifty milliliters of each sample were fixed in $2 \%$ ( $\mathrm{vol} / \mathrm{vol}$ ) glutaraldehyde buffered with phosphate-buffered saline (PBS) and then filtered onto $25 \mathrm{~mm}, 0.2 \mu \mathrm{m}$ black track-etch membrane filters (Whatman). Dimethyl sulfoxide (DMSO) was diluted with PBS to 5\% (vol/vol) as stock solution for SYBR Green II. Both SYBR Green II and the diluted DMSO were passed through $0.2 \mu \mathrm{m}$ filters to remove extraneous particles and cells prior to analysis. Filtered samples were incubated with DMSO-buffered $1 \mathrm{~g} / \mathrm{l} \mathrm{SYBR}$ Green II for at least $15 \mathrm{~min}$ at $20^{\circ} \mathrm{C}$ in the dark. Afterwards the filters were mounted onto a glass slide treated with mounting medium (1:1 mixture of PBS diluted glycerin and $0.1 \% p$-phenylenediamine). Cells on the filters were counted using an Olympus BH-2 microscope with a $405 \mathrm{~nm}$ argon laser at the final magnification of $1000 \times$. The total number of cocci and rods in 60 fields of view was determined, and the number of cells per ml was calculated by computing the cumulative average cell per field (field of view area at $1000 \times$ is $16741 \mu \mathrm{m}^{2}$ ). 

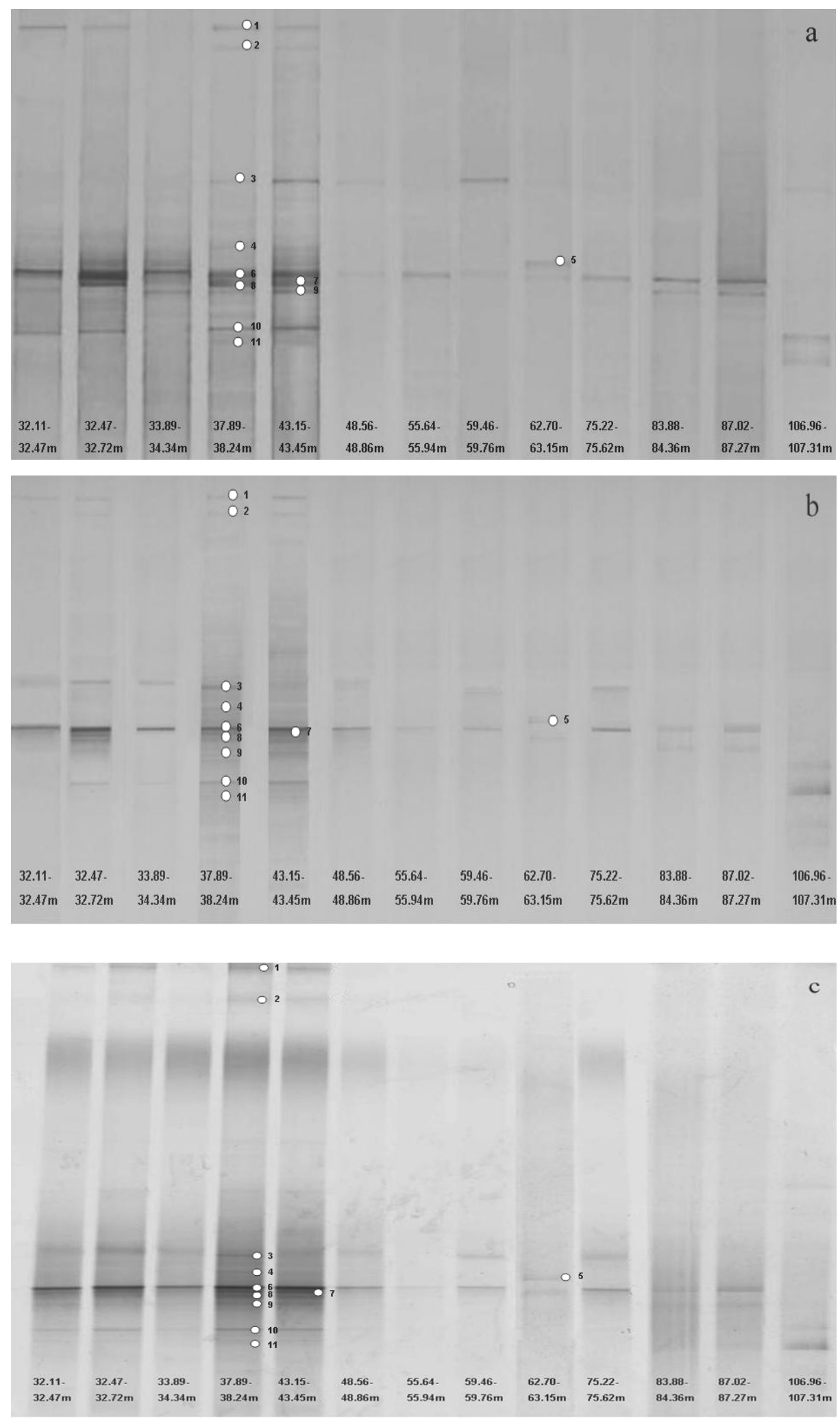

Fig. 2. Three replicates of DGGE profiles of PCR product amplified from 16S rDNA (V3) gene of the ER ice core samples. Numbers at the bottom of the DGGE profiles are their corresponding depth range. 


\subsection{DNA extraction}

Thirteen samples selected from the above 50 were employed for DNA extraction. The remaining $200-1100 \mathrm{ml}$ melted ice core samples were filtrated through $0.22 \mu$ m hydrophilic polyethersulfone membranes (Pall) with a vacuum pump (Ntengwe, 2005). Microorganisms on the membranes were eluted by agitation for $2 \mathrm{~min}$ by hand, then by sonication for 2 min with a sonicator (model 14; Branson Ultrasonics Corp) (Uga et al., 2003) and then suspended in $2.0 \mathrm{ml}$ PBS. Half of the suspension was used for extraction of genomic DNA according to Zhou et al. (1996). The pellets of crude nucleic acid were finally dried and resuspended in $30 \mu \mathrm{l}$ of sterile deionized water and quantified by UV spectrophotometer (UV 7501, Techcomp).

\subsection{PCR amplification}

Bacterial specific primers,
(5'-CGCCCGCCGCGCGCGGCGGGCG
GGGCGGGGGCACGGGGGG-
CCTACGGGAGGCAGCAG-3') and 518R ATTACCGCGGCTGCTGG-3') were used to amplify the V3 hypervariable region (Crump et al., 2003) of the 16S rDNA gene by PCR with the following conditions: $50 \mu \mathrm{g}$ genomic DNA solution, $0.5 \mu \mathrm{M}$ each primer, $1 \times \mathrm{PCR}$ buffer (Promega), $1.5 \mathrm{mM} \mathrm{MgCl}_{2}$ (Promega), $0.2 \mathrm{mM}$ each deoxyribonucleotide triphosphate, $0.5 \mathrm{U}$ Taq DNA Polymerase (Promega), and sterile deionized water to a final volume of $25 \mu 1$. Negative controls, with $1 \mu \mathrm{l}$ of sterile deionized water as template, were included in all sets of PCR to provide a contamination check. The amplification program consisted of $94^{\circ} \mathrm{C}$ for $5 \mathrm{~min} ; 30$ cycles of $94^{\circ} \mathrm{C}$ for $30 \mathrm{~s}, 56^{\circ} \mathrm{C}$ for $30 \mathrm{~s}$, and $72^{\circ} \mathrm{C}$ for $60 \mathrm{~s}$, and a final extension step of $72^{\circ} \mathrm{C}$ for $8 \mathrm{~min}$. All the PCR products were analyzed on $30 \mathrm{~g} / \mathrm{l}$ agarose gels in $1 \times$ TAE buffer, purified with QIA quick PCR mini kit (QIAGEN, Germany) and quantified by UV spectrophotometer (UV 7501, Techcomp).

\subsection{Denaturing gradient gel electrophoresis (DGGE)}

Two hundred and fifty ng of purified amplicons were used in DGGE analysis in $1 \times$ TAE buffer with $80 \mathrm{~g} / 1$ polyacrylamide gels containing a linear denaturant gradient from $25 \%$ to $60 \%$ of urea (Merck) and formamide (Saarchem) (100\% denaturant contains $7 \mathrm{M}$ urea and $40 \%$ formamide ( $\mathrm{vol} / \mathrm{vol})$ ) in a D-Code system (Bio-Rad, Hercules, CA, USA) according to McCaig et al. (2001). Gels were run at a constant temperature of $60^{\circ} \mathrm{C}$, with $100 \mathrm{~V}$ for $14 \mathrm{~h}$. After completion of electrophoresis, gels were fixed overnight (10\% ethanol ( $\mathrm{vol} / \mathrm{vol}), 0.5 \%$ glacial acetic acid ( $\mathrm{vol} / \mathrm{vol}), 89.5 \% \mathrm{H}_{2} \mathrm{O}$ $(\mathrm{vol} / \mathrm{vol})$ ), then incubated by shaking in fresh silver staining solution ( $2 \mathrm{~g} / \mathrm{l}$ silver nitrate) for $20 \mathrm{~min}$, followed by incubation in fresh developing solution $(15 \mathrm{~g} / \mathrm{l} \mathrm{NaOH}, 0.5 \%$ formaldehyde (vol/vol)) until bands appeared. The gels were then fixed for $10 \mathrm{~min}$ in $7.5 \mathrm{~g} / 1 \mathrm{Na}_{2} \mathrm{CO}_{3}$, and preserved in ethanol-glycerol preservative ( $25 \%$ ethanol (vol/vol), $10 \%$ glycerol ( $\mathrm{vol} / \mathrm{vol}), 65 \% \mathrm{H}_{2} \mathrm{O}(\mathrm{vol} / \mathrm{vol})$ ) for at least $15 \mathrm{~min}$ (McCaig et al., 2001). Images of each gel were documented with Image-Scanner (Amersham Pharmacia Biotech). To ensure the reproducibility and reliability of the DGGE banding patterns, three independent PCR amplification and subsequent DGGE analysis were performed in independent trials. DGGE banding patterns were exactly the same for each replicate (Fig. 2).

\subsection{Precautions and controls}

DNA extraction was carried out in a fully equipped and physically isolated clean laboratory dedicated solely to ancient DNA work with separate ventilation systems, surfaces exposed to UV light overnight, and weekly cleaning of surface with bleach. The PCR setup was in a flow clean bench, exposed to UV light during the night. Both extraction and pre-PCR work were carried out with their own sets of lab clothes, lab tools, and unopened reagents (Lydolph et al., 2005). Tools for pre-PCR work were washed in 5\% sodium hypochlorite (Willerslev et al., 1999) and exposed to UV light overnight. Full-body suits, facemasks, and sterile surgical gloves were used. Mock extraction and PCR controls were made to check for possible contamination by extraneous DNA (Willerslev et al., 1999).

\subsection{Statistical analysis of DGGE profiles}

Bacterial community diversity was calculated from the DGGE band profiles. The Shannon-Weaver index of general diversity $\left(H^{\prime}\right)$ was analyzed with the software of Labworks 4.0 (UVP Bioimaging system) based on the number and relative intensity of the bands in a gel lane and was calculated according to the equation (Shannon and Weaver, 1963).

$H^{\prime}=-\sum\left(P_{i} \times \ln \left(P_{i}\right)\right)$

where $P_{i}$ is the relative intensity of the bands in a gel lane and is calculated as:

$P_{i}=n_{i} / N$

where $n_{i}$ is the height of a peak or the relative intensity of the bands in a gel lane as the result of Labworks 4.0. $N$ is the sum of all peak heights in the densitometric curve.

\subsection{Sequences of recovered DGGE bands}

The strips were excised from the DGGE gel into $1.5 \mathrm{ml}$ centrifuging tubes and rinsed with $1 \mathrm{ml}$ sterile distilled water. The rinsed water was discarded after centrifugation. This procedure was repeated three times. Afterwards, the strips were resuspended in $30 \mu \mathrm{l}$ sterile distilled water at $4^{\circ} \mathrm{C}$ overnight (Gast et al., 2004). The suspension was centrifuged in $10000 \times g$ for $1 \mathrm{~min}$ and $2 \mu \mathrm{l}$ of it was used as PCR template of reamplification, with the non-GC-clamped primers 
and programs as DGGE analysis. The PCR products were purified by using Qiaquick purification kit (Qiagen, Hilden, Germany).

The purified DNA fragments were cloned into pGEM ${ }^{\circledR}-$ T Easy Vector (Promega, Madison, Wisconsin). The resulting plasmids were transformed into competent $E$. coli $\mathrm{DH} 5 \alpha$ (Takara) cells and sequenced directly using primer M13F with a state-of-the-art ABI 3730XL96 capillary sequencer. The sequences obtained were compared to those in the GenBank database by BLAST algorithm to identify sequences with a high degree of similarity and were deposited in the EMBL nucleotide sequence database under accession numbers AM292074 to AM292079.

\section{Results and discussion}

\subsection{Decontamination criteria}

To make sure that each inner ice core sample was free of contamination, we analyzed separately each veneer layer and inner core of 25 samples to monitor changes of bacterial concentrations from the surface to the center. Figure 3a shows an example for the change in bacterial concentrations from surface to inner section of the ice core for the depth interval 59.46-59.76 m, indicating apparent contamination for the most outer veneer layer. Bacterial concentrations reduced to a stable low level from the third veneer layer to the center. Thus the low value of the inner core represents an authentic bacterial concentration result.

A control core constructed with Milli-Q-purified water was processed by methods identical with those of the samples. Bacterial concentrations were 14, 11, 9 and 6 cells $/ \mathrm{ml}$ from surface to inner, respectively (Fig. 3b), and they are not significantly different from each other (using Chi-Square test: $p=0.334>0.05$ ). Moreover, the bacterial concentration in each layer of the control core was, at least, one order of magnitude lower than those measured in the ice core samples. Thus the potential contribution to the contamination during the process is the existence of a small DNA segment after autoclaving of the redistilled water, and therefore negligible.

All the mock extraction and PCR controls made to test for false-positive results were negative, demonstrating the authenticity of our DGGE data.

\subsection{Bacterial concentrations}

Figure 4 shows the change of bacterial concentrations along the $108.83 \mathrm{~m}$ ice core, with a fluctuation of $0.02 \times 10^{3}-6.4 \times 10^{3} \mathrm{cells} / \mathrm{ml} \quad$ (mean $=0.71 \times 10^{3}$ cells $/ \mathrm{ml}$, $S D=0.95 \times 10^{3}$ cells $/ \mathrm{ml}, n=50$ ). There was no consistent, monotonous decrease with increasing age of the ice core, but with a high fluctuation during 1712-1911 AD, a period consistent with industrial revolution when boom of the human population and activities caused flourishing microbe in the wide environments of soil, air, marine, etc. It was also reported that bacterial sensitivities to UV light had increased since the industrial revolution (Zhang, 2002).

Because $\mathrm{Ca}^{2+}$ can be regarded as a good proxy for atmospheric dust transport in Himalayan snow and ice (Kang et al., 2002; Kaspari et al., 2007), we compared the bacterial concentrations with $\mathrm{Ca}^{2+}$ concentrations corresponding to the same ice core sections as shown in Fig. 4. It is worth pointing out that $\mathrm{Ca}^{2+}$ and bacterial samples were sampled at different resolution $\left(\sim 0.04 \mathrm{~m}\right.$ per sample for $\mathrm{Ca}^{2+}$ and $0.25-$ $0.48 \mathrm{~m}$ per sample for bacteria), so all $\mathrm{Ca}^{2+}$ concentrations corresponding to the depth range of each bacterial sample were firstly averaged. Among the bacterial samples, four samples were with a length $0.25 \mathrm{~m}$ (corresponding to $7-11$ $\mathrm{Ca}^{2+}$ samples for each of these four samples), eleven samples with a length $0.45 \mathrm{~m}$ (corresponding to $10-19 \mathrm{Ca}^{2+}$ samples), and one sample with a length $0.48 \mathrm{~m}$ (corresponding to $16 \mathrm{Ca}^{2+}$ samples). Paired t-test was performed for the $\mathrm{Ca}^{2+}$ averages between the $0.25 \mathrm{~m}$ and $0.48 \mathrm{~m}$ samples, resulting in insignificant statistical consequences ( $p>0.05)$. As to paired t-test for the $\mathrm{Ca}^{2+}$ averages between the four $0.25 \mathrm{~m}$ and the eleven $0.45 \mathrm{~m}$ samples, 36 out of the total 44 pairs (82\%) suggest insignificant statistical consequences $(p>0.05)$. These statistical results imply that comparison between the $\mathrm{Ca}^{2+}$ averages in different depth range is statistically significant.

The averaged $\mathrm{Ca}^{2+}$ concentrations fluctuate in the range $52.18-745.69 \mathrm{ppb}$ (mean=155.77 ppb, $S D=118.93 \mathrm{ppb}$, $n=50$ ). Figure 4 showed an obvious difference of the distribution trend between the bacterial and $\mathrm{Ca}^{2+}$ concentrations. This is further confirmed by their weak negative correlation $(r=-0.135, p=0.351)$.

Although Yao et al. (2006) suggested that more microorganisms were associated generally with dust layers in the Tibetan Malan ice core, they did not perform a correlation between the bacterial concentrations and insoluble particles. Our analysis from their reported data (Yao et al., 2006) of 6 dirty layers for mineral measurement showed a weak negative correlation between these two parameters $(r=-0.022$, $p=0.967, n=6)$. Moreover, a weak negative correlation $(r=-0.031, p=0.896, n=20)$ was also found between the bacterial and $\mathrm{Ca}^{2+}$ concentrations of 20 samples collected from an $83.45 \mathrm{~m}$ Tibetan Puruogangri ice core from the reported data by Zhang (2006). For all the ice core drilling sites (Fig. 1) in the Himalaya (ER and Yala glaciers), the central TP (Malan and Puruogangri glaciers), or the northern TP (Muztagh Ata Glacier), the correlation between bacterial concentrations/biomass and micro-particle concentrations is insignificant. Therefore, there might be other factors, together with micro-particles serving as a nutrition source for bacteria, that determine bacterial concentrations in glacial ice. For instance, algal biomass in annual layers of a shallow ice core from the Yala Glacier was found to be correlated significantly with two indices of snow-cover thickness, which determines the intensity of light available for algal growth, as well as the amount and period of availability 

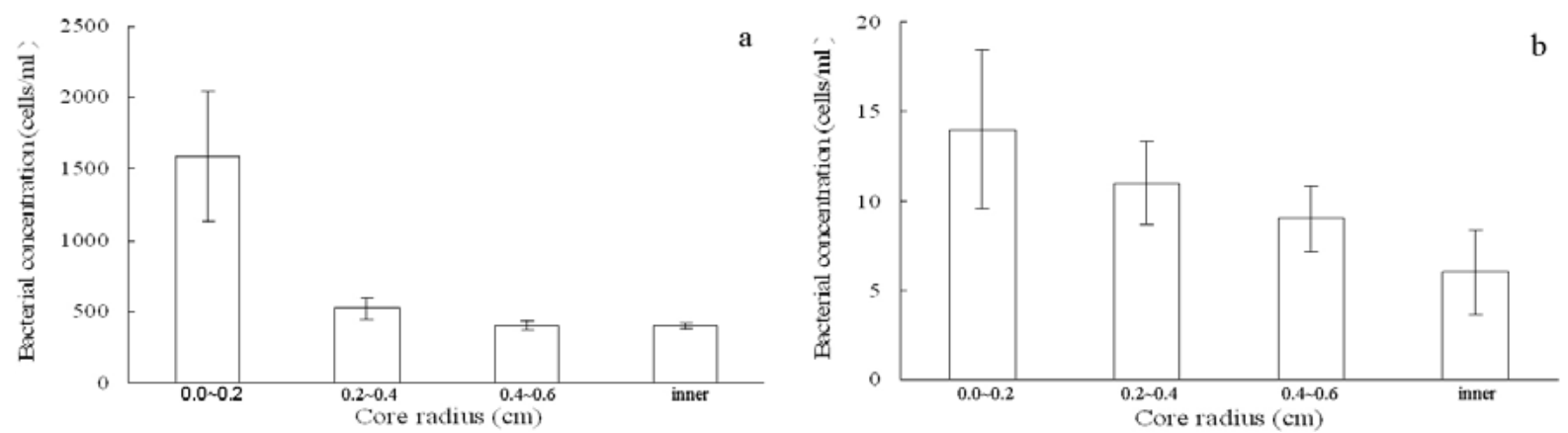

Fig. 3. Change in bacterial concentrations from surface to inner core of the samples. (a) example of ice core section for the depth interval 59.46-59.76 m; (b) artificial ice sample.

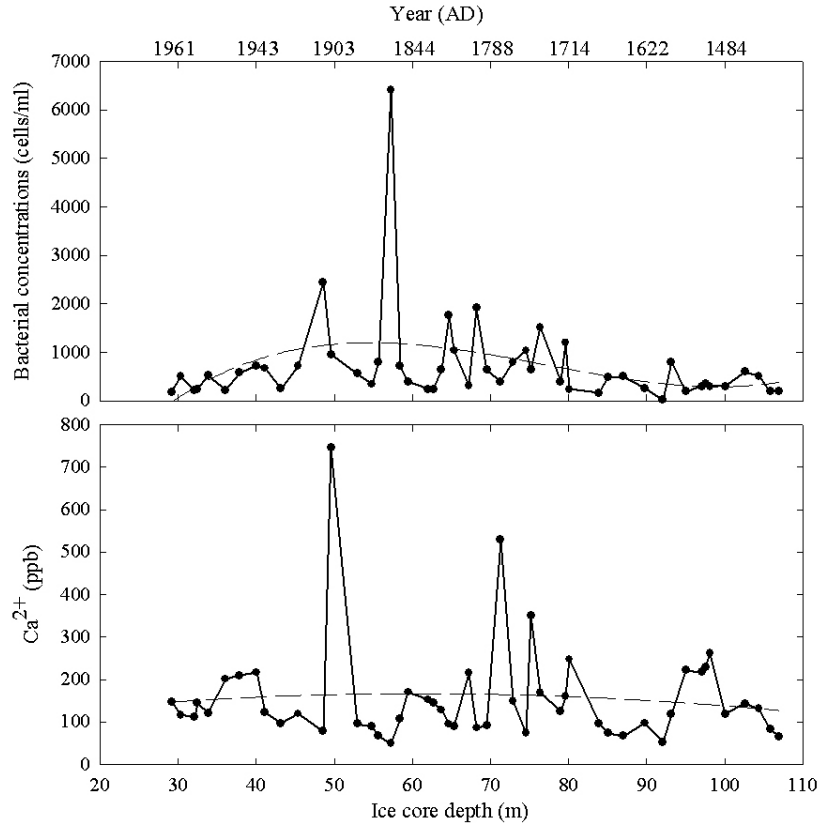

Fig. 4. Profiles of bacterial and $\mathrm{Ca}^{2+}$ concentrations along the ER ice core. Dashed lines through the data sets indicate the third-order regression.

of snow meltwater (Yoshimura et al., 2006). These results demonstrate that not only the relatively perplexing source of microorganisms, but also the complex growth mechanisms of bacterial community can be promoted by different nutrilites or environmental conditions in glaciers (Segawa et al., 2005). Given the ambiguous relationship between bacterial concentrations and ice core parameters, more efforts are needed for the reconstruction of past climatic and environmental changes by means of microbiological concentrations.
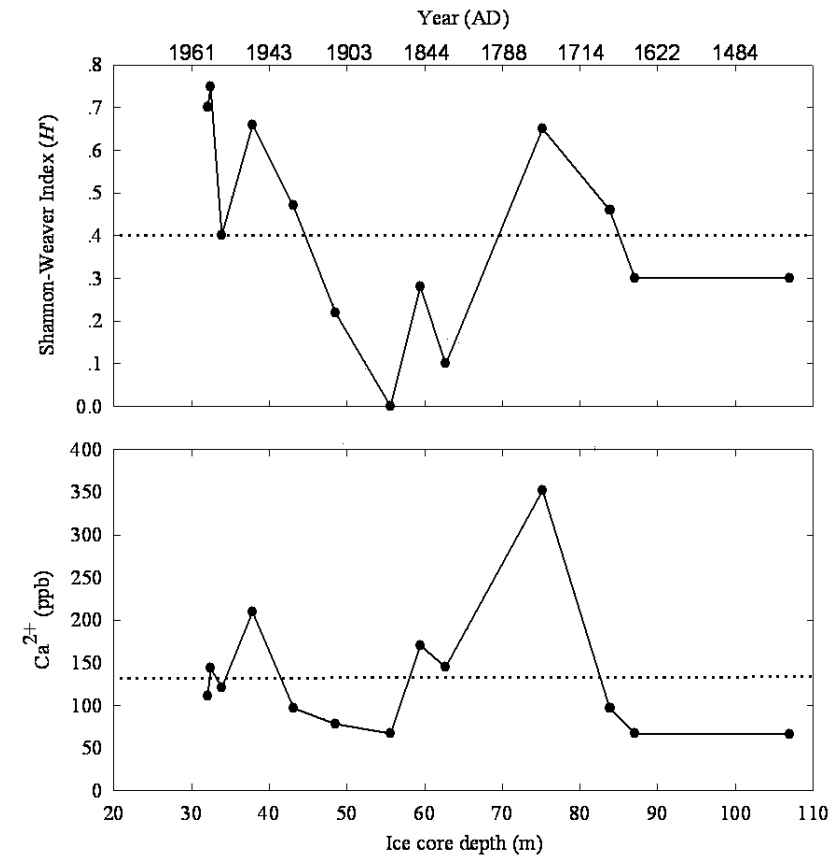

Fig. 5. Vertical distribution of Shannon-Weaver index and $\mathrm{Ca}^{2+}$ concentrations along the ER ice core. Dotted lines through the data sets indicate their mean values, respectively.

3.3 Bacterial community diversity with DGGE and $H^{\prime}$ index analysis

Among the 50 samples for DNA study, the extraction was successful only for the 13 samples that were not evenly spaced along the core. The $H^{\prime}$ index, reflecting the structural diversity of bacterial community, fluctuates in the range of 0-0.75 (mean=0.41, SD=0.19, $n=13$ ), and the $\mathrm{Ca}^{2+}$ average is $132.65 \mathrm{ppb}(S D=78.87 \mathrm{ppb}, n=13)$ in response to these 13 samples (Fig. 5). Considering $\mathrm{Ca}^{2+}$ as a proxy for the atmospheric dust transport to our study site, there are two high dust periods from 32.11 to $37.89 \mathrm{~m}$ (1947-1958 $\mathrm{AD})$ and 59.46 to $75.22 \mathrm{~m}$ (1752-1847 AD), two low dust 
Table 1. Signal intensity and phylogenetic affiliation for bacteria in the ER ice core, as determined by DGGE sequencing.

\begin{tabular}{|c|c|c|c|c|c|c|c|c|c|c|c|c|c|c|c|c|}
\hline \multirow[b]{2}{*}{$\begin{array}{l}\text { Band } \\
\text { no. }^{\text {a }}\end{array}$} & \multicolumn{13}{|c|}{ Signal intensity (\%) } & \multirow{2}{*}{$\begin{array}{l}\text { Most closely } \\
\text { related } \\
\text { organism }\end{array}$} & \multirow[b]{2}{*}{ Taxonomic group } & \multirow{2}{*}{$\begin{array}{l}\text { Sequence } \\
\text { similarity } \\
(\%)\end{array}$} \\
\hline & $\begin{array}{l}32.11- \\
32.47 \mathrm{~m}\end{array}$ & $\begin{array}{l}32.47- \\
32.72 \mathrm{~m}\end{array}$ & $\begin{array}{l}33.89- \\
34.34 \mathrm{~m}\end{array}$ & $\begin{array}{l}37.89- \\
38.24 \mathrm{~m}\end{array}$ & $\begin{array}{l}43.15- \\
43.45 \mathrm{~m}\end{array}$ & $\begin{array}{l}48.56- \\
48.86 \mathrm{~m}\end{array}$ & $\begin{array}{l}55.64- \\
55.94 \mathrm{~m}\end{array}$ & $\begin{array}{l}59.46- \\
59.76 \mathrm{~m}\end{array}$ & $\begin{array}{l}62.70- \\
63.15 \mathrm{~m}\end{array}$ & $\begin{array}{l}75.22- \\
75.62 \mathrm{~m}\end{array}$ & $\begin{array}{l}83.88- \\
84.36 \mathrm{~m}\end{array}$ & $\begin{array}{l}87.02- \\
87.27 \mathrm{~m}\end{array}$ & $\begin{array}{l}106.96- \\
107.31 \mathrm{~m}\end{array}$ & & & \\
\hline 1 & 12.4 & 12.6 & $\mathrm{ND}^{\mathrm{b}}$ & 15.0 & 7.4 & ND & ND & ND & ND & ND & ND & ND & ND & $\begin{array}{l}\text { Acinetobacter } \\
\text { sp. }\end{array}$ & $\gamma$-proteobacteria & $100 \%$ \\
\hline 2 & ND & 12.0 & ND & 9.7 & 7.3 & ND & ND & ND & ND & ND & ND & ND & ND & $\begin{array}{l}\text { uncultured } \\
\text { bacterium }\end{array}$ & $\beta$-proteobacteria & $100 \%$ \\
\hline 3 & ND & ND & ND & 15.0 & ND & ND & ND & ND & ND & ND & ND & ND & ND & $\begin{array}{l}\text { Caldaterra } \\
\text { satsumae }\end{array}$ & Firmicutes & $87 \%$ \\
\hline 4 & ND & ND & ND & 12.6 & ND & ND & ND & ND & ND & ND & ND & ND & ND & $\begin{array}{l}\text { uncultured } \\
\text { bacterium }\end{array}$ & $\gamma$-proteobacteria & $95 \%$ \\
\hline 6 & 27.6 & 33.9 & 57.1 & 31.3 & 48.6 & 74.7 & 100 & 66.8 & ND & 60.9 & 50.4 & 68.3 & ND & $\begin{array}{l}\text { uncultured } \\
\text { bacterium }\end{array}$ & $\gamma$-proteobacteria & $99 \%$ \\
\hline 8 & ND & 15.8 & ND & 6.8 & 19.5 & ND & ND & ND & 63.1 & ND & ND & ND & ND & $\begin{array}{l}\text { Lentibacillus } \\
\text { juripiscarius }\end{array}$ & Firmicutes & $89 \%$ \\
\hline
\end{tabular}

a Band no., number as indicated on Fig. 2.

${ }^{\mathrm{b}} \mathrm{ND}$, not detected.

periods from 43.15 to $55.64 \mathrm{~m}$ (1868-1932 AD) and 83.88 to 106.96 m (1054-1686 AD). Accordingly, bacterial community diversity shows a similar trend against the above four periods (Fig. 5). A significantly positive correlation $(r=0.486$, $p=0.092, n=13$ ) is observed between these two parameters, which is consistent with that of the Tibetan Puruogangri ice core ( $r=0.71, P<0.01, n=13)$ (Zhang et al., 2006).

Dust storm outbreaks over the TP are associated with the movement of westerlies (Xu et al., 2007). During the cold periods of Little Ice Age (LIA), the westerlies were enhanced resulting in higher than normal precipitation and large seasonal snow cover over central Asia, thus the dust concentrations decreased. However, during the relatively warm periods of LIA, the intensity of westerlies weakened resulting in low precipitation in the winter and spring seasons and smaller than normal seasonal snow cover (Xu, J., Hou, S., Qin, D., Kaspari, S., Mayewski, P., Petit, J. R., Delmonte, B., Kang, S., Ren, J., Chappellaz, J., Hong, S.: A $108.83 \mathrm{~m}$ ice core record of atmospheric dust deposition in Mt. Qomolangma (Everest), central Himalaya, Quaternary Res., 2008, revised). As a consequence, the dust concentrations increased, resulting in desiccation reduction and protection of microorganisms necessary for their survival (Priscu et al., 1998). Greater bacterial diversity associated with micro-particles than that in the free-living fraction was also reported in the subseafloor habitat (Huber et al., 2002, 2003) and in the Tibetan Puruogangri ice core (Zhang et al., 2006).

3.4 Vertical distribution of the most dominant component with DGGE analysis

A total of 11 bands were labeled and excised from the gels (Fig. 2). We finally got six 16S rDNA sequences (Table 1). Half of the sequences were similar to the uncultured eukaryote sequences, suggesting that the corresponding lineages were uncultured groups of bacteria. Fifty percent of the sequences were with low similarity (87-95\%) to the known bacteria in GenBank. Thus their corresponding bacteria were probably undescribed.
The sequences of the samples were affiliated with 3 phylogenetic groups: $\beta$-, $\gamma$-proteobacteria and Firmicutes. The most intense bands in the profiles corresponded to $\gamma$ proteobacteria group, which was observed almost throughout the ER ice core. The other groups of Firmicutes and $\beta$ Proteobacteria were also represented and detected in four and three different core sections, respectively. The dominance of $\gamma$-proteobacteria in the ER ice core was consistent to that in the Muztagh Ata ice core (Xiang et al., 2004), water, ice and sediment samples from the Bench Glacier of Alaska and the John Evans Glacier of Canada (Skidmore, et al., 2005).

The apparent differences of bacterial community diversity at different depth of the ER ice core probably reflected an imprint of climate change (Xiang et al., 2004; Zhang et al., 2006). For instance, band sites $1-4$ occurred within the ER ice core depth ranges 32.11-32.47 m, 32.47-32.72 m, 33.89$34.34 \mathrm{~m}$ 37.89-38.24 m, and 43.15-43.45 m, which coincide with the periods of high $\mathrm{Ca}^{2+}$ concentrations. Thus it is likely that nutrition served by dust is a determinant factor for the bacteria corresponding to these band sites.

\section{Conclusions}

The quantitative distribution of bacterial population preserved in a Himalayan glacier displays a dissimilar variation trend to $\mathrm{Ca}^{2+}$ concentrations, and a weak negative correlation was observed between them. However, the ShannonWeaver index showed a certain similarity with $\mathrm{Ca}^{2+}$ concentrations. Therefore, dust concentrations might be more important in determining bacterial community diversity than bacterial concentrations in the Himalayan glaciers. Because only 13 samples were employed for deducing such a relationship between $\mathrm{Ca}^{2+}$ concentrations and bacterial community diversity, further detailed investigation with more samples are needed to better understand the distribution mechanism of bacterial abundance and community diversity in the glacial ice. This is crucial for the suitability of glacial 
microorganisms as a potential new indicator of past climatic and environmental changes.

Acknowledgements. Thanks are due to many scientists, technicians, students and porters for their hard work expertly carried out in the field, to Jo Jacka for revising the manuscript. This work was supported by National Basic Research program of China (Grant No 2007CB411501), the Chinese Academy of Sciences (Grant No KZCX3-SW-344 and 100 Talents Project), and the Natural Science Foundation of China (Grant No 40825017 and 40576001 ).

Edited by: T. J. Battin

\section{References}

Christner, B. C., Mikucki, J. A., Foreman, C. M., Denson, J., and Priscu, J. C.: Glacial ice cores: a model system for developing extraterrestrial decontamination protocols, Icarus, 174, 572-584, 2005.

Crump, B. C., Kling, G. W., Bahr, M., and Hobbie, J. E.: Bacterioplankton community shifts in an Arctic lake correlate with seasonal changes in organic matter source, Appl. Environ. Microb., 69, 2253-2268, 2003.

Gast, R. J., Dennett, M. R., and Caron, D. A.: Characterization of protistan assemblages in the Ross Sea, Antarctica, by denaturing gradient gel electrophoresis, Appl. Environ. Microb., 70, 20282037, 2004.

Hou, S., Qin, D., Yao, T., Zhang, D., and Chen, T.: Recent change of the ice core accumulation rates on the Qinghai-Tibetan Plateau, Chinese Sci. Bull., 47, 1746-1749, 2002.

Hou, S., Jouzel, J., Chappellaz, J., Qin, D., Masson-Delmotte, V., von Grafenstein, U., Landais, A., and Caillon, N.: Age of Himalayan bottom ice cores, J. Glaciol., 50, 467-468, 2004.

Huber, J. A., Butterfield, D. A., and Baross, J. A.: Temporal changes in archaeal diversity and chemistry in a mid-ocean ridge subseafloor habitat, Appl. Environ. Microb., 68, 1585-1594, 2002.

Huber, J. A., Butterfield, D. A., and Baross, J. A.: Bacterial diversity in a subseafloor habitat following a deep-sea volcanic eruption, FEMS Microbiol. Ecol., 43, 393-409, 2003.

Ivask, J., Pentchuk, J., and Vaikmäe, R.: Ion chromatographic determination of major anions and cations in Antarctic ice, Proc. Estonian Acad. Sci. Chem., 50, 46-51, 2001.

Kang, S., Mayewski, P. A., Qin, D., Yan, Y., Hou, S., Zhang, D., Ren, J., and Kruetz, K.: Glaciochemical records from a Mt. Everest ice core: relationship to atmospheric circulation over Asia, Atmos. Environ., 36, 3351-3361, 2002.

Kaspari, S., Mayewski, P., Kang, S., Sneed, S., Hou, S. Hooke, R., Kreutz, K., Introne, D., Handley, M., Maasch, K., Qin, D., and Ren, J.: Reduction in northward incursions of the South Asian monsoon since 1400 AD inferred from a Mt. Everest ice core, Geophys. Res. Lett., 34, L16701, doi:10.1029/2007GL030440, 2007

Kaspari, S., Hooke, R., Mayewski, P. A., Kang, S., Hou, S., and Qin, D.: Snow accumulation rate on Mt. Everest: synchroneity with sites across the Tibetan Plateau on 50-100 year timescales, J. Glaciol., 54, 343-352, 2008.
Lydolph, M. C., Jacobsen, J., Arctander, P., Thomas, M., Gilbert, P., Gilichinsky, D. A., Hansen, A. J., Willerslev, E., and Lange, L.: Beringian paleoecology inferred from permafrost-preserved fungal DNA, Appl. Environ. Microb., 71, 1012-1017, 2005.

McCaig, A. E., Glover, L. A., and Prosser, J. I.: Numerical analysis of grassland bacterial community structure under different land management regimens by using $16 \mathrm{~S}$ ribosomal DNA sequence data and denaturing gradient gel electrophoresis banding patterns, Appl. Environ. Microb., 67, 4554-4559, 2001.

Mitskevich, I. N., Poglazova, M. N., Abyzov, S. S., Barkov, N. I., Bobin, N. E., and Ivanov, M. V.: Microorganisms found in the basal horizons of the Antarctic glacier above Lake Vostok, Dokl. Biol. Sci., 381, 420-423, 2001.

Ntengwe, F. W.: An overview of industrial wastewater treatment and analysis as means of preventing pollution of surface and underground water bodies - the case of Nkana Mine in Zambia, Phys. Chem. Earth, 30, 726-734, 2005.

Priscu, J. C., Fritsen, C. H., Adams, E. E., Giovannoni, S. J., Paerl, H. W., McKay, C. P., Doran, P. T., Gordon, D. A., Lanoil, B. D., and Pinckney, J. L.: Perennial Antarctic lake ice: an oasis for life in a polar desert, Science, 280, 2095-2098, 1998.

Segawa, T., Miyamoto, K., Ushida, K., Agata, K., Okada, N., and Koshima, S.: Seasonal change in bacterial flora and biomass in mountain snow from the Tateyama mountains, Japan, analyzed by $16 \mathrm{~S}$ rDNA gene sequencing and Real-Time PCR, Appl. Environ. Microb., 71, 123-130, 2005.

Shannon, C. E. and Weaver, W.: A mathematical theory of communication, 2nd ed, Illinois Univ. Press, Urbana, 226 pp., 1963.

Skidmore, M., Anderson, S. P., Sharp, M., Foght, J., and Lanoil, B. D.: Comparison of microbial community compositions of two subglacial environments reveals a possible role for microbes in chemical weathering processes, Appl. Environ. Microb., 71, 6986-6997, 2005.

Uga, S., Oda, T., Kimura, K., Kimura, D., Koesdarto, S., Margono, S., Nuvit, K., and Apakupakul, N.: Detection of microorganisms in tap water in Indonesia and Thailand, Jpn. J. Trop. Med. Hyg., 31, 87-91, 2003.

Willerslev, E., Hansen, A. J., Christensen, B., Steffensen, J. P., and Arctander, P.: Diversity of Holocene life forms in fossil glacier ice, P. Natl. Acad. Sci. USA, 96, 8017-8021, 1999.

Xiang, S., Yao, T., An, L., Li, Z., Wu, G., Wang Y., Xu, B., and Wang J.: Change of bacterial community in the Malan Ice Core and its relation to climate and environment, Chinese Sci. Bull., 49, 1869-1875, 2004.

Xiang, S., Yao, T., Wu, G., Chen, Y., Shang, T., Pu, L., and An, L.: Deposition on properties of bacterial populations in the Muztag Ata ice core, Quat. Sci., 26, 185-191, 2006 (in Chinese).

Xu, J., Hou, S., Qin, D., Ren, J., and Ming, J.: Dust storm activity over the Tibetan Plateau recorded by a shallow ice core from the north slope of Mt. Qomolangma (Everest), Tibet-Himal region, Geophys. Res. Lett., 34, L17504, doi: 10.1029/2007GL030853, 2007.

Yamagishi, T., Hishinuma, T., and Kataoka, H.: Bicarbonate enhances synchronous division of the giant nuclei of sporophytes in Bryopsis plumose, J. Plant. Res., 116, 295-300, 2003.

Yao, T., Xiang, S., Zhang, X., Wang, N., and Wang, Y.: Microorganisms in the Malan ice core and their relation to climatic and environmental changes, Global Biogeochem. Cy., 20, GB1004, doi:10.1029/2004GB002424, 2006. 
Yoshimura, Y., Kohshima, S., Takeuchi, N., Seko, K., and Fujita, K.: Snow algae in a Himalayan ice core: new environmental markers for ice core analyses and their correlation with summer mass balance, Ann. Glaciol., 43, 148-153, 2006.

Zhang, S., Hou, S., Ma, X., Qin, D., and Chen, T.: Culturable Bacteria in the East Rongbuk Glacier, Mt. Qomolangma (Everest) in response to atmospheric circulation, Biogeosciences, 4, 1-9, 2007 ,

http://www.biogeosciences.net/4/1/2007/.

Zhang, X.: Diversity of microorganisms and DNA entrapped in glacier ice of Qinghai-Tibet Plateau and its relation with environment, Ph.D. thesis, Cold and Arid Reg. Environ. Eng. Res. Inst., Chin. Acad. of Sci. at Lanzhou, China, 2002.
Zhang, X.: Diversity of microorganisms entrapped in Puruogangri ice core and its relation to environment, Ph.D. thesis, Cold and Arid Reg. Environ. Eng. Res. Inst., Chin. Acad. of Sci. at Lanzhou, China, 2006.

Zhang, X., Yao, T., An, L., Tian, L., and Xu, S.: A study on the vertical profile of bacterial DNA structure in the Puruogangri (Tibetan Plateau) ice core using denaturing gradient gel electrophoresis, Ann. Glaciol., 43, 160-166, 2006.

Zhang, X., Ma, X., Yao, T., and Zhang, G.: Diversity of 16S rDNA and environmental factor influencing bacteria in Malan ice core, Chinese Sci. Bull., 48(11), 1146-1151, 2003.

Zhou, J., Bruns, M. A., and Tiedje, J. M.: DNA recovery from soils of diverse composition, Appl. Environ. Microb., 62, 361-322, 1996. 